\title{
Stromal impact on tumor growth and lymphangiogenesis in human carcinoma xenografts
}

\author{
Elin Hadler-Olsen • Hilde Ljones Wetting • Oddveig Rikardsen • Sonja E. Steigen • \\ Premasany Kanapathippillai • Reidar Grénman • Jan-Olof Winberg • \\ Gunbjørg Svineng • Lars Uhlin-Hansen
}

Received: 17 June 2010 /Revised: 10 August 2010/Accepted: 12 September 2010 /Published online: 3 October 2010

(C) The Author(s) 2010. This article is published with open access at Springerlink.com

\begin{abstract}
Squamous cell carcinomas (SCCs) arising in the oral cavity are associated with poor survival, mainly due to metastatic disease. In contrast, skin SCCs rarely metastasize and are usually curable. To study influence of tongue and skin stroma on cancer growth and induction of lymphangiogenesis, xenograft tumors of human carcinoma cells were established either in tongue or skin of BALB/c nude mice. Two oral and two skin SCC cell lines were used, as well as an endometrial adenocarcinoma cell line. Tongue tumors established from all cell lines were larger than corresponding skin tumors. Peritumoral lymphatic vessel density was up to five times higher in tongue than in corresponding skin tumors, and mRNA level of the
\end{abstract}

E. Hadler-Olsen $(\bowtie) \cdot$ P. Kanapathippillai $\cdot$ J.-O. Winberg $\cdot$

G. Svineng $\cdot$ L. Uhlin-Hansen

Department of Medical Biology, Faculty of Health Sciences,

University of Tromsø,

9037 Tromsø, Norway

e-mail: elin.hadler-olsen@uit.no

H. L. Wetting

Department of Pharmacy, Faculty of Health Sciences,

University of Tromsø,

Tromsø, Norway

O. Rikardsen

Ear, Nose and Throat Department,

University Hospital North Norway,

Tromsø, Norway

S. E. Steigen · L. Uhlin-Hansen

Department of Pathology, University Hospital North Norway,

Tromsø, Norway

R. Grénman

Department of Otorhinolaryngology, Head and Neck Surgery,

University of Turku and Turku University Hospital,

Turku, Finland lymphangiogenic growth factor vascular endothelial growth factor (VEGF)-C was twice as high in tongue tumors compared with corresponding skin tumors. Contrary to lymphatic vessel density, blood vessel density was higher in skin tumors than in tongue tumors. In a cohort of patient samples, lymphatic vessel density was found to be higher in tongue SCCs compared with skin SCCs, supporting a clinical relevance of our findings. Our results show that the tumor stroma has a profound impact on cancer growth and induction of lymphangiogenesis and angiogenesis. The difference in lymphatic vessel density between tongue and skin tumors may be important in directing metastatic potential of tumors arising in these organs.

Keywords Mouse model - Orthotopic · Oral cancer · Skin cancer $\cdot$ Lymphangiogenesis $\cdot$ Angiogenesis

\section{Introduction}

Squamous cell carcinomas (SCCs) can arise in various locations of the body, including skin, oral mucosa, esophagus, lungs and cervix, but the tumor aggressiveness is dependent on the "host" organ. Oral SCCs are characterized by an aggressive behavior and associated with a low 5-year survival rate, mainly because of metastatic disease $[1,2]$. In contrast, skin SCCs seldom metastasizes, and most patients have a very good prognosis [3].

It is well recognized that cancer growth and progression are strongly influenced by the non-malignant part of the tumor, the tumor stroma, which is composed of an extracellular matrix (ECM) and various cells types such as fibroblasts, smooth muscle cells, endothelial cells and inflammatory cells [4]. Malignant cells communicate with and modify their microenvironment through the release of 
various molecules, as well as by cell-cell and cell-matrix contacts. When stimulated, the stromal cells influence cancer progression by producing growth factors and proteases that modulate growth, apoptosis, angiogenesis, lymphangiogenesis, invasion and metastasis $[5,6]$.

The importance of angiogenesis in cancer progression is well documented [7]. Less focus has been on the role of lymphangiogenesis, although SCCs mainly metastasize via lymphatic vessels [8]. The lack of reliable markers of lymphatic endothelial cells has held back studies on lymphangiogenesis, but recently more specific markers have been identified which have given rise to increased knowledge of the role of the lymphatic system in cancer [9-11]. Many cancer types, such as melanomas, oral, cervical, and non-small cell lung cancers can induce lymphangiogenesis, and lymphatic vessel density is often correlated with metastases and poor survival [12-15].

A large number of cytokines and growth factors are reported to affect angiogenesis and lymphangiogenesis. Vascular endothelial growth factor (VEGF)-C and VEGF-D are important lymphangiogenic growth factors [16, 17], mediating proliferation, survival and increased migration of cultured human lymphatic endothelial cells [17]. VEGF-C knockout mice die in utero due to a complete lack of lymphatic vessels and subsequent accumulation of fluid in the tissues [16]. The VEGF-C deficient phenotype can be rescued by VEGF-D [16], indicating an overlapping function of these growth factors. Both factors are secreted from various cell types in an active form that can bind their principal receptor, VEGFR-3. In normal adult tissue, this receptor is restricted to lymphatic endothelial cells, but can also be expressed on tumor vascular endothelial cells $[10,18-20]$. In the extracellular environment VEGF-C and VEGF-D can be processed by proteases to a mature form with higher affinity for VEGFR-3 [19, 21].

In order to investigate the role of the stroma for tumor growth and lymphangiogenesis, we established a xenograft model in which different human carcinoma cell lines were injected in the tongue or the skin of BALB/c nude mice. Cancer cells are reported to grow faster and be more aggressive in the orthotopic environment compared with a heterotopic environment $[22,23]$. To control for this effect, we used cell lines established from skin and tongue SCCs, as well as an endometrial adenocarcinoma cell line. Independently of orthotopic or heterotopic growth of the tumor cells, we found that the tumor stroma had a strong impact on several aspects of tumor progression, including growth and lymphangiogenesis.

\section{Materials and methods}

Cell lines and culturing

The human cancer cell lines and culture media used are listed in Table 1. The HSC-4 cell line was a kind gift from Professor M. Yanagishita, Tokyo Medical and Dental University, Japan. The establishment of the UT-SCC-7 and UT-SCC-12A cell lines is done as described in Grénman et al. [24]. The SCC-25 cell line was purchased from ATCC (Manassas, VA), and the Ishikawa cells from Sigma-Aldrich (St. Louis, MO). All cell lines were incubated in a humidified atmosphere of $5 \% \mathrm{CO}_{2}$ at $37^{\circ} \mathrm{C}$.

Animals and establishment of xenograft tumors

To determine a suitable number of cells to be injected, pilot studies were performed. A concentration of 300,000 cells in $25 \mu \mathrm{l} 0.9 \% \mathrm{NaCl}$ was chosen. Cultured cells were detached by trypsin treatment $(0.25 \%$ in PBS with $0.05 \%$ $\mathrm{Na}_{2}$ EDTA), washed once in serum containing cell culture medium, once in $0.9 \% \mathrm{NaCl}$ and thereafter resuspended in $0.9 \% \mathrm{NaCl}$ at a concentration of 12 million cells $/ \mathrm{ml}$. Six- to 8-week-old BALB/c nude mice (Harlan Laboratories,

Table 1 Cell lines and culture media

\begin{tabular}{|c|c|c|}
\hline Cell line & Origin & Medium \\
\hline SCC-25 & Tongue SCC & $\begin{array}{l}\mathrm{DMEM} / \mathrm{HamF}-12,10 \% \mathrm{FBS}, 0.5 \mathrm{mM} \text { L-glutamine, } 50 \mathrm{U} \\
\text { penicillin and } 50 \mu \mathrm{g} / \mathrm{ml} \text { streptomycin, } 400 \mathrm{ng} / \mathrm{ml} \\
\text { hydrocortisone }\end{array}$ \\
\hline HSC-4 & Lymph node metastasis of tongue SCC & $\begin{array}{l}\text { DMEM, } 10 \% \text { FBS, } 0.5 \mathrm{mM} \text { L-glutamine, } 50 \mathrm{U} \text { penicillin and } \\
50 \mu \mathrm{g} / \mathrm{ml} \text { streptomycin }\end{array}$ \\
\hline UT-SCC-12A & Skin SCC, nose & $\begin{array}{l}\text { DMEM, } 10 \% \text { FBS, } 0.5 \mathrm{mM} \text { L-glutamine, } 50 \mathrm{U} \text { penicillin } \\
\text { and } 50 \mu \mathrm{g} / \mathrm{ml} \text { streptomycin, } 0.1 \mathrm{mM} \text { non-essential amino acids }\end{array}$ \\
\hline UT-SCC-7 & Lymph node metastasis of skin SCC, regio temporalis & $\begin{array}{l}\text { DMEM, } 10 \% \text { FBS, } 0.5 \mathrm{mM} \text { L-glutamine, } 50 \mathrm{U} \text { penicillin and } \\
50 \mu \mathrm{g} / \mathrm{ml} \text { streptomycin, } 0.1 \mathrm{mM} \text { non-essential amino acids }\end{array}$ \\
\hline Ishikawa & Endometrial adenocarcinoma & $\begin{array}{l}\text { RPMI } 1640,10 \% \text { FBS, } 0.5 \mathrm{mM} \text { L-glutamine, } 50 \mathrm{U} \text { penicillin and } \\
50 \mu \mathrm{g} / \mathrm{ml} \text { streptomycin }\end{array}$ \\
\hline
\end{tabular}


Indianapolis, IN) were anaesthetised with a mixture of $0.5 \mathrm{mg}$ ketamine and $0.1 \mathrm{mg}$ xylazine hydrochloride subcutaneously before $25 \mu$ l of cancer cell suspension was injected into the anterior part of the tongue or subcutaneously on the abdomen. For each cell line tongue tumors were established in 12 mice and skin tumors in 12 mice, except for the UT-SCC-7 cell line from which six tongue and six skin tumors were established. The mice were weighed every second day to ensure that they did not lose more than $10 \%$ of their body weight, and were sacrificed with $\mathrm{CO}_{2}$ after 5-28 days. Tumors were either fixed in a $\mathrm{Zn}$-based fixative (ZBF) $\left(36.7 \mathrm{mM} \mathrm{ZnCl}, 27.3 \mathrm{mM} \mathrm{ZnAc} 2 \times 2 \mathrm{H}_{2} \mathrm{O}\right.$ and $0.63 \mathrm{mM} \mathrm{CaAc} 2$ in $0.1 \mathrm{~mol} / 1$ Tris $\mathrm{pH}$ 7.4) or submerged in RNAlater (Sigma-Aldrich St. Louis, MO) immediately after the mice were sacrificed. Draining lymph nodes were fixed in $\mathrm{ZBF}$, whereas liver and lungs were fixed in $4 \%$ neutral buffered formalin (NBF). Blood samples were collected, mixed with heparin $(15 \mathrm{U} / \mathrm{ml}$ heparin blood) and centrifuged at $11,000 \times g$ for $5 \mathrm{~min}$ before plasma was isolated. The project was approved by the Norwegian Animal Research Authority.

\section{Metastasis}

ZBF-fixed lymph nodes were paraffin embedded, sectioned and $\mathrm{H} / \mathrm{E}$-stained to look for metastases. The presence of metastases was confirmed by immunohistochemical staining with a pan cytokeratin antibody (Zymed laboratories, purchased from Invitrogen, Carlsbad, CA). NBF-fixed livers and lungs were sliced and examined for metastases under a dissecting microscope. In addition, lymphatic permeation of cancer cells was assessed on sections of tongue and skin tumors of the various cell lines immunohistochemically stained with the lymphatic endothelial cell marker Lyve-1. The sections/samples were scored as positive if clusters of cancer cells were found within one or more lumens with Lyve-1-positive lining.
Tumor size

ZBF-fixed tongue and skin tumors were dehydrated, paraffin embedded (oriented in the same way) and serially sectioned to measure the size of the tumors. During sectioning, the area of the tumor was studied in a light microscope (Leica DM2000, Leica, Wetzlar, Germany). The sections with the largest tumors were $\mathrm{H} / \mathrm{E}$ stained, and the tumor area was accurately measured using a Leica Application Suite Interactive measurement tool (Leica, Wetzlar, Germany). The mean area was calculated based on the five largest tumors in tongue and skin of each cell line, except for the HSC-4 cell line where only three detectable skin tumors were found at each time point. Tumor size was measured after 28 days of in vivo growth for all cell lines except the UT-SCC12A cell line for which tumors were measured after 15 days of in vivo growth.

Immunohistochemistry

Four-micrometer thick sections of ZBF-fixed, paraffinembedded tissue from the mouse xenograft model or of formalin-fixed human tongue or skin SCCs on Superfrost Plus slides were analyzed by immunohistochemistry. The antibodies, dilutions and incubation conditions are listed in Table 2. Horseradish peroxidase (HRP)-labeled secondary antibody and diaminobenzidine (DAB)-substrate (EnVision $^{+}$system-HRP for rabbit primary antibodies, Dako, Glostrup, Denmark or Ventana XT Ultra View Universal DAB, Tucson, AZ) were used for visualization. Immunohistochemistry was performed as previously described [25]. The CD31 and CD68 antibodies were monoclonal rat anti-mouse antibodies, and immunohistochemical procedure for these antibodies included a linking rabbit anti-rat antibody (Dako 1:400). Sections where primary antibody was omitted and replaced by $1.5 \%$ normal goat serum were used as negative controls. Staining for
Table 2 Antibodies

\footnotetext{
${ }^{\text {a }}$ Antigen retrieval $1.3 \mathrm{mg} / \mathrm{ml}$ Pepsin 30 min RT

Abbreviations: $R T$ room temperature, $O N$ over night
}

\begin{tabular}{lll}
\hline Antibody & Dilution & Incubation \\
\hline Rabbit anti-bovine cytokeratin(Pan) pab, Zymed Laboratories \# 08-0059 & Predilute & 1 h RT \\
Rabbit anti-human PHH-3 pab, Millipore \# 06-570 & $1: 500$ & 32 min., RT \\
Rabbit anti-human caspase-3 active pab, R\&D systems \# AF835 & $1: 900$ & 30 min., RT \\
Rat anti-mouse CD-31 mab, BD Pharmingen \#550274 & $1: 10$ & ON, $4^{\circ} \mathrm{C}$ \\
Rabbit anti-mouse Lyve-1 pab, AbCam \# ab14917 & $1: 1,000$ & 30 min., RT \\
Mouse anti-human D2-40, Dako \# M3619 & $1: 25$ & 32 min., RT \\
Rabbit anti-human VEGF-C pab, Zymed Laboratories \# 182255 & $1: 150$ & ON, $4^{\circ} \mathrm{C}$ \\
Rabbit anti-human VEGF-D pab, Santa Cruz \# sc-13085 & $1: 100$ & ON, $4^{\circ} \mathrm{C}$ \\
Rat anti-mouse CD-68 mab, AbCam \# ab53444 & $1: 600$ & 30 min., RT \\
Rabbit anti-rat immunoglobulins, Dako \# E0468 & $1: 400$ & 30 min., RT \\
\hline
\end{tabular}


podoplanin (D2-40) and PHH-3 was performed using a Ventana (Tucson, AZ) automated immunohistochemical stainer according to the manufacturer's instructions. Unless otherwise specified, staining of xenograft tumors were performed on tumors after 28 days of in vivo growth for all cell lines except the UT-SCC-12A cell line from which tumors were analyzed after 15 days of in vivo growth.

Fraction of mitotic and apoptotic cells

To calculate the fraction of cells undergoing apoptosis and mitosis, immunohistochemical staining with the apoptotic marker active caspase-3, and the proliferation marker PHH3 were performed. Three apoptotic/mitotic hotspots were recognized at low power magnification $(40 \times)$ in three parallel tongue and skin tumors of each cell line. The fraction of apoptotic and mitotic cells were determined by calculating the mean number of apoptotic or mitotic cells per total number of cells on photographs taken with a Leica DFC 420 camera on a Leica DM2000 microscope (Leica, Wetzlar, Germany) of the hotpots at high-power magnification $(400 \times)$.

\section{Determination of blood vessel density}

Sections of normal tongue and skin tissue of BALB/c nude mice, as well as tongue and skin xenograft tumors of the various cell lines were stained with the vascular endothelial cell marker CD31. For each cell line mean vessel density (MVD) was calculated according to the method described by Weidner et al. [26]. Three vascular hotspots were recognized at low power magnification $(40 \times)$ in three parallel tongue and skin tumors of each cell line. Lumens with CD31-positive lining were counted in each hotspot at $200 \times$ magnification to calculate the MVD. In addition, MVD was measured by counting lumens containing erythrocytes on $\mathrm{H} / \mathrm{E}$-stained sections. These calculations were performed the same way as the CD31 counting, except that five parallel tongue and skin tumors were evaluated for each cell line, and counting was performed at $400 \times$ magnification. Vessel density was calculated in the tumor and in the stromal tissue within a $0.5 \mathrm{~mm}$ radius from the outer border of a tumor island.

\section{Determination of lymphatic vessel density}

Sections of tongue and skin xenograft tumors of each cell line, as well as normal tongue and skin tissue of $\mathrm{BALB} / \mathrm{c}$ nude mice, were stained with the lymphatic endothelial cell marker Lyve-1. Peritumoral lymphatic vessel density was calculated as the mean of three hotspots per section for at least three parallel tumors, as a modification of the method described by Weidner et al.
[26]. Hotspots were recognized at low power magnification and counted at 200× magnification. Each hotspot had an area of $0.25 \mathrm{~mm}^{2}$ and was located within a radius of $0.5 \mathrm{~mm}$ from the outer border of a tumor island. Only lymphatic vessels with an evident lumen were counted. Intratumoral lymphatic vessel density was calculated for tumors with intratumoral lymphatic vessels. Three visual fields containing hotspots were recognized per tumor and counted at $200 \times$ magnification. In addition, 21 skin and 21 tongue SCCs, randomly chosen from the archives of the Surgical Pathology Department at the University Hospital North Norway, were immunohistochemically stained with the lymphatic endothelial cell marker D2-40. For each tumor, three hotspots were recognized at $100 \times$ magnifications and counted at $200 \times$ magnification. The mean number of lymphatic vessels per visual field was calculated.

\section{Immunohistochemical scoring of VEGF-C and VEGF-D}

Immunohistochemical staining with antibodies against the lymphangiogenic growth factors VEGF-C and VEGF-D were scored according to Kobel et al. [27]. Staining intensity of the tumor cells was designated as non-existent (0), weak (1), moderate (2) or strong (3). The number of positive cells was scored as no cells stained (0), less than $10 \%$ (1), $10-50 \%$ (2), $51-80 \%$ (3) or more than $80 \%$ (4). The final score was calculated by multiplication of these two variables.

\section{Quantification of VEGF-C and VEGF-D mRNA}

Tumor samples were separated from stroma under a dissecting microscope and homogenized in a TissueLyzer homogenizer (Qiagen, Hilden, Germany) with 5-mm steal beads. Total RNA was extracted using RNeasy Fibrous Tissue Mini kit (Qiagen, Hilden, Germany) according to the manufacturer's instructions. On-column DNase treatment of the RNA samples was performed using Qiagen's RNase-Free DNase set according to the product manual. Quantity and purity of the extracted RNA was determined using the NanoDrop spectrophotometer (Thermo Fisher Scientific, Wilmington, DE), and RNA integrity was assessed using the Experion-automated electrophoresis system (Bio-Rad Laboratories, Hercules, CA). VEGF-C and VEGF-D mRNA expression levels were quantified by reverse transcription quantitative PCR (RTqPCR) performed on a Stratagene Mx3000P instrument (Stratagene, La Jolla, CA). Primers for SYBR Green based assays were purchased from Qiagen (Hilden, Germany) (listed in Table 3). Primer specificities and absence of primer dimers were determined by SYBR Green melting curve analysis. Reverse transcription of 
Table 3 QuantiTec primer assays from Qiagen

\begin{tabular}{lllcl}
\hline Gene symbol & Assay name & Cat.no & Amplicon length (bp) & RefSeq accession number \\
\hline VEGF-C & Hs_VEGFC_1_SG & QT00061579 & 96 & NM_005429 \\
VEGF-D & Hs_FIGF_1_SG & QT00003997 & 138 & NM_004469 \\
ACT-B & Hs_ACTB_1_SG & QT00095431 & 146 & NM_001101 \\
TFRC & Hs_TFRC_1_SG & QT00094850 & 81 & NM_001128148 \\
\hline
\end{tabular}

total RNA was performed using Reverse Transcriptase Core Kit (Eurogentec, SA, Searing, Belgium) with random nonamer primers according to the manufacturer's recommendations, using $200 \mathrm{ng}$ RNA per $10-\mu \mathrm{l}$ cDNA reaction. cDNA corresponding to $20 \mathrm{ng}$ RNA was amplified for 40 cycles in a $25-\mu 1$ PCR mix $\left(\right.$ RT $^{2}$ Real-Time ${ }^{\mathrm{TM}}$ SYBR Green/ROX PCR Master Mix (SA Biosciences, Frederick, $\mathrm{MD})$ ). Cycling conditions: $95^{\circ} \mathrm{C}$ for $10 \mathrm{~min}, 40$ cycles at $95^{\circ} \mathrm{C}$ for $30 \mathrm{~s}$ and $60^{\circ} \mathrm{C}$ for $1 \mathrm{~min}$. Duplicate reverse transcription reactions were performed for each RNA sample, and duplicate PCR analyses were performed on each cDNA sample. The absence of genomic DNA was confirmed by performing a no reverse transcription control, and absence of contaminations was assessed by including a no template control in every run. The deltadelta $\mathrm{Ct}$ method [28] was used to determine the relative amount of target gene in the tumor samples normalized against the average expression of the two reference genes $A C T-B$ and $T F R C$.

\section{Quantification of myeloid cells}

CD68 staining was performed to evaluate proportion of macrophages, Langerhans cells and dendritic cells in the inflammatory infiltrate. The number of CD68-positive cells surrounding both tongue and skin tumors was very low, therefore no detailed scoring of this staining was performed. To evaluate number of mast cells in the inflammatory infiltrate, chemical staining with MayGrünwald-Giemsa was performed following standard procedures on three parallel tongue and skin tumors of each cell line. Three mast cell hotspots within a radius of $0.5 \mathrm{~mm}$ from the outer border of a tumor island were recognized in each section and counted at $400 \times$ magnification. Furthermore, an assessment of the inflammatory infiltrate was made on $\mathrm{H} / \mathrm{E}$-stained sections of tongue and skin tumors of the different cell lines. The extent of inflammatory reaction was assessed and scored as negligible (0), weak (1), moderate (2) or strong (3). The proportion of neutrophils in the inflammatory infiltrate was evaluated, based on morphological characteristics, and scored as $<1 \%(0), 1-30 \%$ (1), 31-70\% (2) or $>70 \%$ (3). The number of neutrophils was then estimated by multiplication of these two variables.
Quantification of serum amyloid P in plasma

To measure the level of the major mouse acute phase protein serum amyloid P (SAP) in circulation, plasma from mice with tongue and skin tumors of the various cell lines were subjected to enzyme-linked immunoassay using a Mouse Serum Amyloid P ELISA kit (Kamiya Biomedical Company, Seattle, WA). Samples were diluted 1:10,000, and the assay was performed according to the product manual.

\section{Statistics}

Two-tailed $t$ tests were used to evaluate differences between tongue and skin tumors for the different parameters analyzed. Data are presented as means \pm standard error of the mean (SEM). Independent replicates $(N)$ for the different data are identified in tables and figure legends. $P$ values $<0.05$ were accepted as statistically significant. Graphics and statistical analyses were performed using SPSS 15.0 for Windows.

\section{Results}

Tumors in tongue and skin of $\mathrm{BALB} / \mathrm{c}$ nude mice were established by injecting 300,000 cancer cells at each site in separate animals. Five different human cell lines were used, two oral and two skin SCCs, as well as an endometrial adenocarcinoma cell line (Table 1). The mice were sacrificed 15 or 28 days after cancer cell injection, except for mice with tumors of the skin SCC cell line UT-SCC12A. This cell line grew faster than the other cell lines in tongue, and therefore all mice with UT-SCC-12A tumors were sacrificed after 15 days.

All cell lines formed larger tumors in tongue than in skin

It is well known that tumor size is an important prognostic factor. To study how the microenvironment in the tongue and the skin affected tumor growth, we measured the size of the tumors as described in the "Materials and methods" section. This revealed that all cell lines formed larger tumors in the tongue than in the skin. The average area of the SCC-25, HSC-4 and UT-SCC-12A tongue tumors were seven to 17 
times larger than the corresponding skin tumors, while the differences were smaller for tumors of the UT-SCC-7 and Ishikawa cell lines (Figs. 1 and 2). In addition to being smaller, the skin tumors of the UT-SCC-12A and HSC- 4 cell lines often regressed spontaneously during the first 2 weeks. Although all mice had detectable tumors 1 week after injection, 14 out of 18 animals injected with UT-SCC-12A cells in the skin had detectable tumors after 14 days, and only nine out of 18 animals injected with HSC-4 cells in the skin had detectable tumors after 28 days. The number of cells injected in skin was raised to five million, but still the tumors often regressed during the first 2 weeks.

The fraction of mitotic and apoptotic cells was calculated for the skin and tongue tumors of the various cell lines, as a difference in one or both of these parameters would be expected based on the observed discrepancy in tumor size. For all cell lines a higher fraction of mitotic cells was seen in the tongue tumors compared with the skin tumors (Table 4), whereas the fraction of apoptotic cells showed only minor differences between the skin and tongue tumors for all cell lines (Table 5).

Lymph node metastases from tongue tumors were detected, but not from skin tumors

In general, oral SCCs are characterized by frequent lymph node metastases, while skin SCCs seldom metastasize. In tumors from our xenograft model, regional lymph node metastasis were detected in nine out of 18 of the tongue tumors of the skin SCC cell line UT-SCC-12A (Fig. 3a), and also from two out of 18 of the tongue tumors of the Ishikawa cell line. No metastases were detected from tongue tumors of the other cell lines or from any of the skin tumors. Lymphatic permeation of cancer cells was found in ten out of 31 evaluated tongue tumors (Fig. 3b) and in four out of 27 evaluated skin tumors stained with the lymphatic endothelial cell marker Lyve-1.

Blood vessel density was higher in skin tumors than in tongue tumors

Sections of the various tongue and skin tumors from our xenograft model were immunohistochemically stained with the vascular endothelial cell marker CD31 (Fig. 4a-d), and MVD determined in order to investigate if vascularisation was correlated to tumor size. Surprisingly, the skin tumors showed a higher MVD than the corresponding tongue tumors (data not shown). Within some tongue tumors there were endothelial cells that had lost CD31 positivity, evident as unstained tubular structures containing red blood cells (Fig. 4d). As this made the CD31-based calculations somewhat uncertain, MVD was also calculated by counting lumens containing erythrocytes on H/E-stained sections. These calculations confirmed the results obtained by counting CD31-positive tubular structures. The MVD for skin tumors of the UTSCC-12A, UT-SCC-7 and Ishikawa cell lines were on average 2.3 times higher than for the corresponding tongue tumors, while smaller differences were seen between skin and tongue tumors of the SCC-25 and HSC-4 cell lines (Fig. 4e). MVD for tongue tumors of all cell lines pooled was significantly higher than MVD for skin tumors of all cell lines pooled (Fig. 4e). MVD was also calculated in normal tongue and skin, by counting CD31-positive tubular structures in hotspots in the anterior, free moving part of the tongue as well as in the
Fig. 1 Size of tongue and skin tumors. Graph shows mean area in $\mathrm{mm}^{2}$ ( \pm SEM) of tongue (black bars) and skin (grey bars) tumors of the various cell lines. $N=5$ for SCC-25, UT-SCC-12A, UT-SCC-7 and Ishikawa tumors. $N=3$ for skin tumors and $N=5$ for tongue tumors of the HSC-4 cell line. $N=25$ for pooled tongue tumors, and $N=23$ for pooled skin tumors of all cell lines. ${ }^{*} P<0.01$

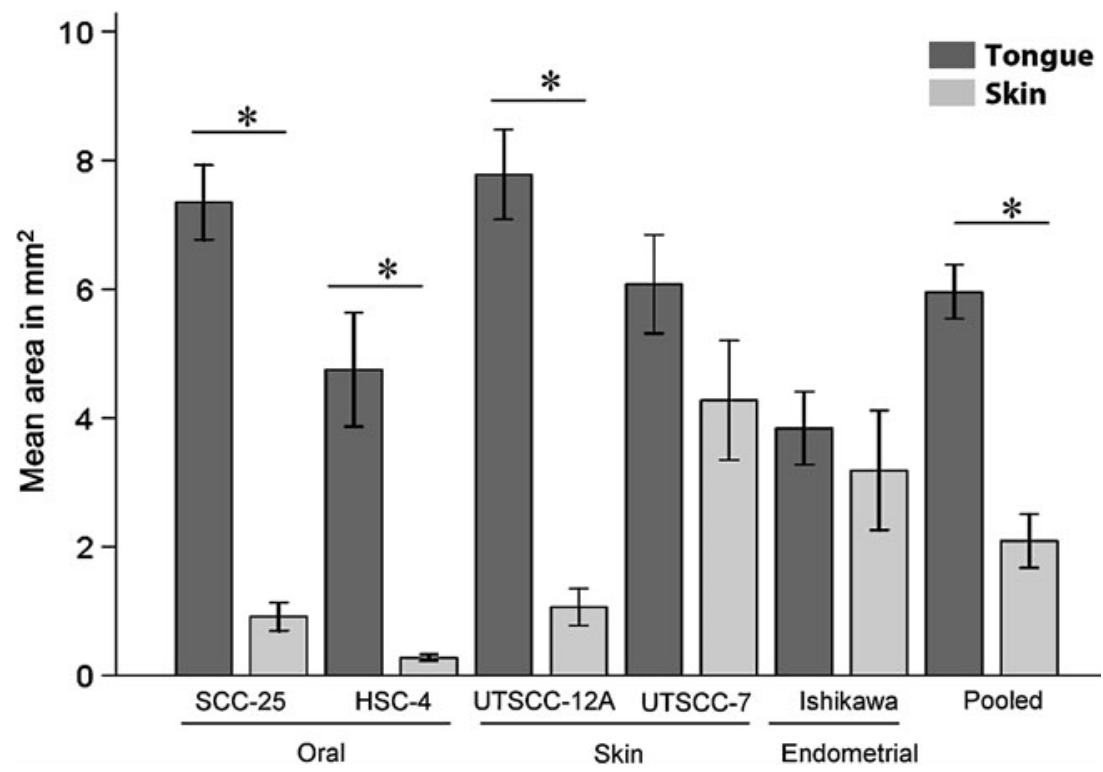


Fig. $2 \mathrm{H} / \mathrm{E}$ staining of tongue and skin tumors. $\mathrm{H} / \mathrm{E}$-stained sections of representative tongue tumors $(\mathbf{a}, \mathbf{c}, \mathbf{e}, \mathbf{g}$ and $\mathbf{i})$ and skin tumors (b, $\mathbf{d}, \mathbf{f}, \mathbf{h}$ and $\mathbf{j})$ of the SCC-25 (a and b), HSC-4 (c and d), UT-SCC-12A (e and f), UTSCC-7 (g and h) and Ishikawa (i and $\mathbf{j}$ ) cell lines. Labeling indicates: $t$ tumor, $s$ stroma, $m$ striated muscle, asterisk keratinous pearl; arrow surface epithelium. Original magnification, $100 \times$
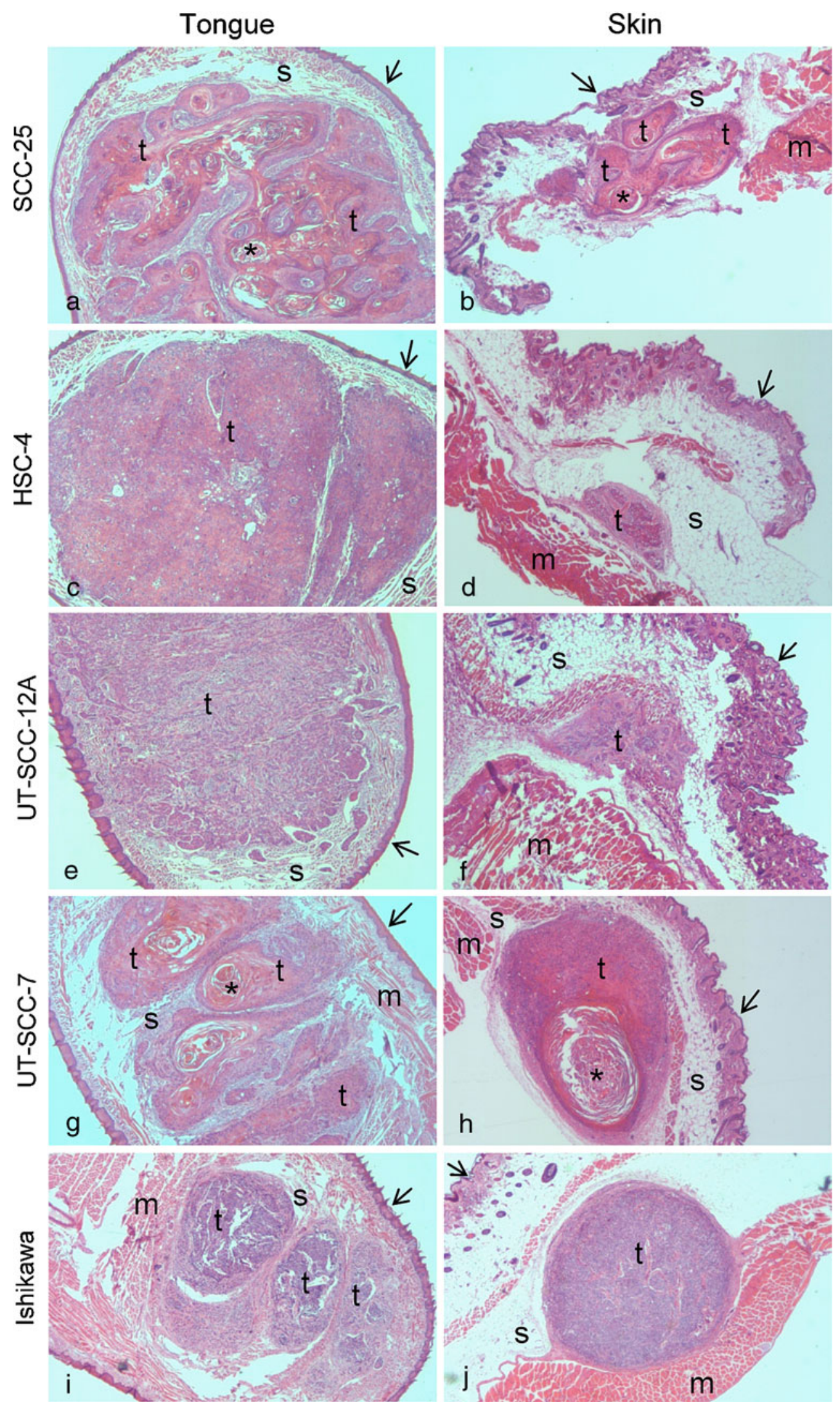
Table 4 Fraction of mitotic cells

\begin{tabular}{lccc}
\hline Cell line & \multicolumn{2}{l}{ Mean \pm SEM } & $P$ \\
\cline { 2 - 3 } & Tongue & Skin & \\
\hline SCC-25 & $46 \pm 10$ & $30 \pm 4$ & 0.341 \\
HSC-4 & $26 \pm 13$ & $14 \pm 1$ & 0.455 \\
UT-SCC-12A & $58 \pm 4$ & $15 \pm 4$ & 0.001 \\
UT-SCC-7 & $100 \pm 53$ & $47 \pm 5$ & 0.422 \\
Ishikawa & $66 \pm 9$ & $51 \pm 8$ & 0.257 \\
Pooled & $61 \pm 12$ & $31 \pm 5$ & 0.038 \\
\hline
\end{tabular}

$N=3$ for all cell lines, except SCC-25 skin where $N=2 . N=15$ for pooled tongue tumors and $N=14$ for pooled skin tumors

skin. This revealed that blood vessel density was similar in these two sites (data not shown).

Lymphatic vessel density was higher in tongue tumors than in skin tumors

Lymphatic vessel density is found to correlate with lymph node metastases in many cancers. We therefore investigated if lymphatic vessel density differed between tongue and skin tumors in our xenograft model. Tongue and skin tumors, as well as normal tongue and skin tissue of the mice, were immunohistochemically stained with the lymphatic endothelial cell marker Lyve-1 (Fig. 5a, b). Positive staining was seen in tubular structures. None of these contained red blood cells, supporting that these were lymphatic vessels. In the normal tongue and skin tissue of the mice, no difference in lymphatic vessel density was observed between the two different sites (results not shown). In the tumor tissue, lymphatic vessels were mainly seen in the stroma surrounding the tumor. In addition, intratumoral lymphatic vessels were seen in some tumors,

Table 5 Fraction of apoptotic cells

\begin{tabular}{llll}
\hline Cell line & \multicolumn{2}{l}{ Mean \pm SEM } & $P$ \\
\cline { 2 - 3 } & Tongue & Skin & \\
\hline SCC-25 & $23 \pm 84$ & $24 \pm 9$ & 0.957 \\
HSC-4 & $63 \pm 24$ & $90 \pm 66$ & 0.679 \\
UT-SCC-12A & $20 \pm 6$ & $30 \pm 10$ & 0.456 \\
UT-SCC-7 & $18 \pm 5$ & $13 \pm 5$ & 0.555 \\
Ishikawa & $43 \pm 13$ & $55 \pm 27$ & 0.708 \\
Pooled & $35 \pm 7$ & $40 \pm 12$ & 0.689 \\
\hline
\end{tabular}

$N=2$ for SCC-25 skin, HSC-4 skin and UT-SCC-7 tongue, $N=3$ for SCC-25 tongue, HSC-4 tongue, UT-SCC-12A tongue and skin, UTSCC-7 skin and Ishikawa tongue and skin. $N=14$ for pooled tongue tumors and $N=13$ for pooled skin tumors primarily in the tongue. Peritumoral lymphatic vessel density was up to five times higher in tongue compared with skin tumors (Fig. 5c). Functional lymphatic vessels (containing a lumen) were almost completely absent surrounding the skin tumors of the oral SCC cell lines SCC-25 and HSC-4. The other cell lines seemed to be able to induce formation of new lymphatic vessels in association with the skin tumors, but to a much lesser extent than in the tongue. In the tongue, numerous lymphatic vessels surrounded the tumors. These vessels were often concentrated in hotspots towards the basis of the tongue. To study the time course of lymphangiogenesis, tongue tumors of the HSC-4 cell line were stained with Lyve-1 after 5, 10 and 15 days of tumor growth. Five days after cancer cell injection (Fig. 6a), the number of lymphatic vessels surrounding the tumors was about the same as in the normal tongue, while a marked increase was seen both within and surrounding the tumors from day 5 till days 10 and 15 after cancer cell injection (Fig. 6b, c).

In addition to staining of lymphatic vessels, some Lyve1-positive single cells were seen in the tissue surrounding both tongue and skin tumors. Lyve-1 is reported to be expressed by tumor associated macrophages [29] and by high-endothelial venules of lymph nodes [30]. There is also evidence that lymphatic endothelial progenitor cells and multi-potent mesenchymal stem cells can contribute to formation of lymphatic vessels [31-34]. The Lyve-1positive single cells may represent one or several of these cell types.

\section{Increased expression of VEGF-C in tongue tumors}

Three parallel tongue and skin tumors of each cell line were stained with antibodies against VEGF-C and VEGF-D to determine if different expression of these growth factors could explain the observed distinction in lymphatic vessel density between tongue and skin tumors from our xenograft model. Three parallel tongue and skin tumors of each cell line were stained with antibodies against VEGF-C and VEGF-D. In all tumors, staining for both growth factors was primarily seen in the cancer cells, but some stromal cells were also positive (Fig. 7). The staining varied between the parallels and no significant differences were observed between tongue and skin tumors of the various cell lines (data not shown).

To more precisely quantify the expression of VEGF-C and VEGF-D, the mRNA level of both growth factors was analyzed by RT-qPCR in five tongue tumors and four skin tumors of the Ishikawa cell line. The expression of VEGF$\mathrm{C}$ mRNA was about twice as high in tongue tumors compared with skin tumors $(2.1 \pm 0.37$ (mean \pm SEM)), whereas no difference was found in the expression level of VEGF-D (data not shown). 


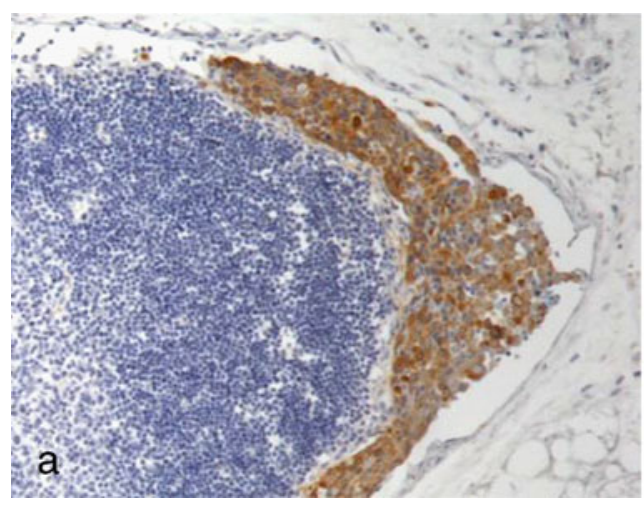

Fig. 3 Lymphatic metastases. a Lymph node metastases from a xenograft tongue tumor of the skin SCC cell line UT-SCC-12A immunohistochemically stained with cytokeratin. Cytokeratin staining is shown in brown and nuclei are stained blue. Original magnification,

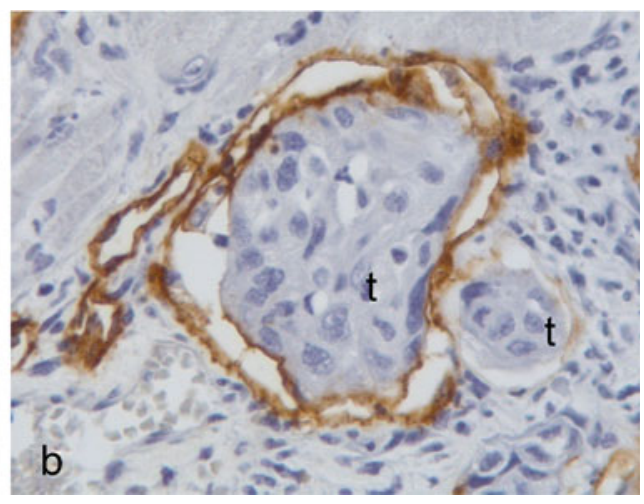

$100 \times$. b Tongue lymphatic vessels immunohistochemically stained with Lyve-1 containing UT-SCC-12A tumor cells (labeled $t$ ). Lyve-1 staining is shown in brown and cell nuclei are stained blue. Original magnification, $400 \times$
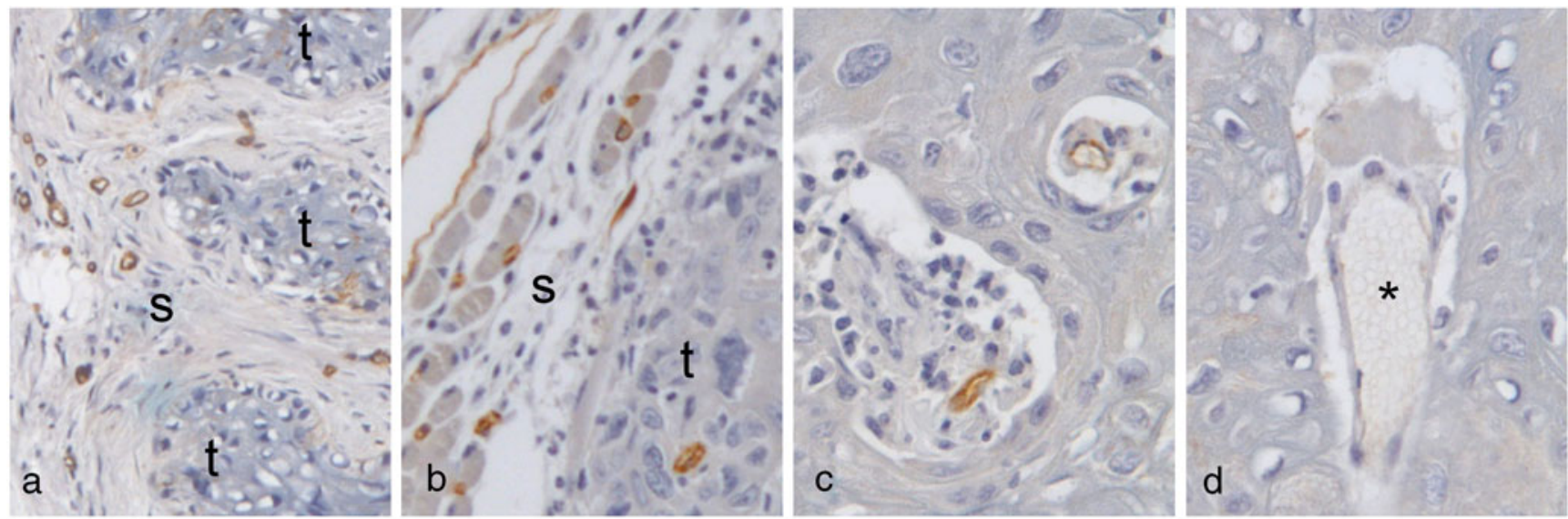

e
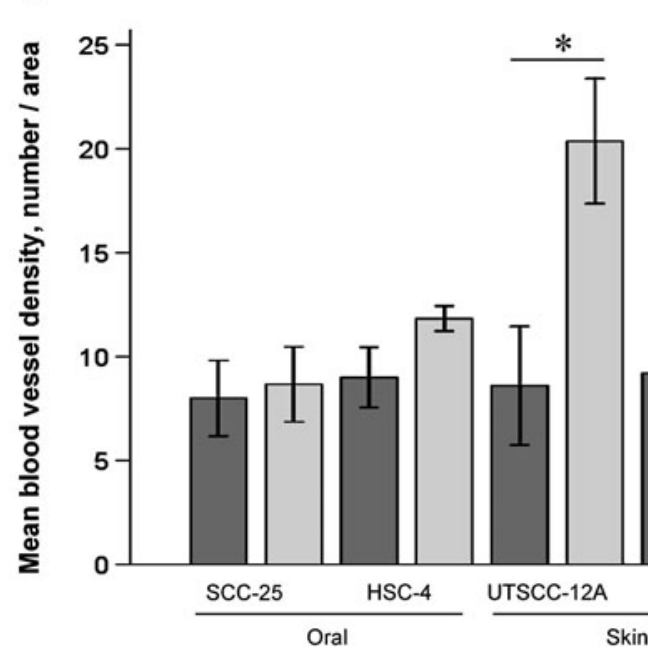

$\frac{\text { UTSCC-12A }}{\text { Skin }}$
Tongue

Skin
Fig. 4 Blood vessel density. Pictures show representative immunohistochemical CD31 staining of a skin tumor and $\mathbf{b}$ tongue tumor of the oral SCC cell line HSC-4. CD31 staining is shown in brown and cell nuclei are stained blue. Tumor and stromal areas are indicated with $t$ and $s$, respectively. Original magnification, 100×. c CD31-positive blood vessels within intratumoral stromal tissue of a tongue tumor of the HSC-4 cell line. Original magnification, 400×. d CD31-negative blood vessel within the same tumor as in c). Blood vessel without
CD31 staining is labeled with asterisk. Original magnification, 400×. e Graph shows mean blood vessel density (MVD; \pm SEM) of tongue (black bars) and skin (grey bars) tumors of the different cell lines, calculated by counting lumens containing red blood cells. $N=5$ for SCC-25, UT-SCC-12A, UT-SCC-7 and Ishikawa tumors. $N=3$ for skin tumors and $N=5$ for tongue tumors of the HSC- 4 cell line. $N=25$ for pooled tongue tumors, and $N=23$ for pooled skin tumors of all cell lines. ${ }^{*} P<0.05$ 
Fig. 5 Lymphatic vessel density. Pictures show representative immunohistochemical Lyve-1 staining of tumors of the HSC-4 cell line in $\mathbf{a}$ tongue and $\mathbf{b}$ skin. Lyve-1 staining is shown in brown and cell nuclei are stained blue. Tumor and stromal areas are indicated with $t$ and $s$, respectively. Original magnification, 100×. c Graph shows peritumoral mean lymphatic vessel density ( \pm SEM) of tongue (black bars) and skin (grey bars) tumors of the various cell lines as number of vessels per area. $N=6$ for SCC-25 and UT-SCC-12A tumors, $N=4$ for UT-SCC-7 and Ishikawa tumors. $N=6$ for HSC- 4 tongue tumors, and $N=3$ for HSC-4 skin tumors. $N=26$ for pooled tongue tumors, and $N=24$ for pooled skin tumors of all cell lines. ${ }^{*} P<0.05$; $* *$ $P<0.005$

\section{Tongue}
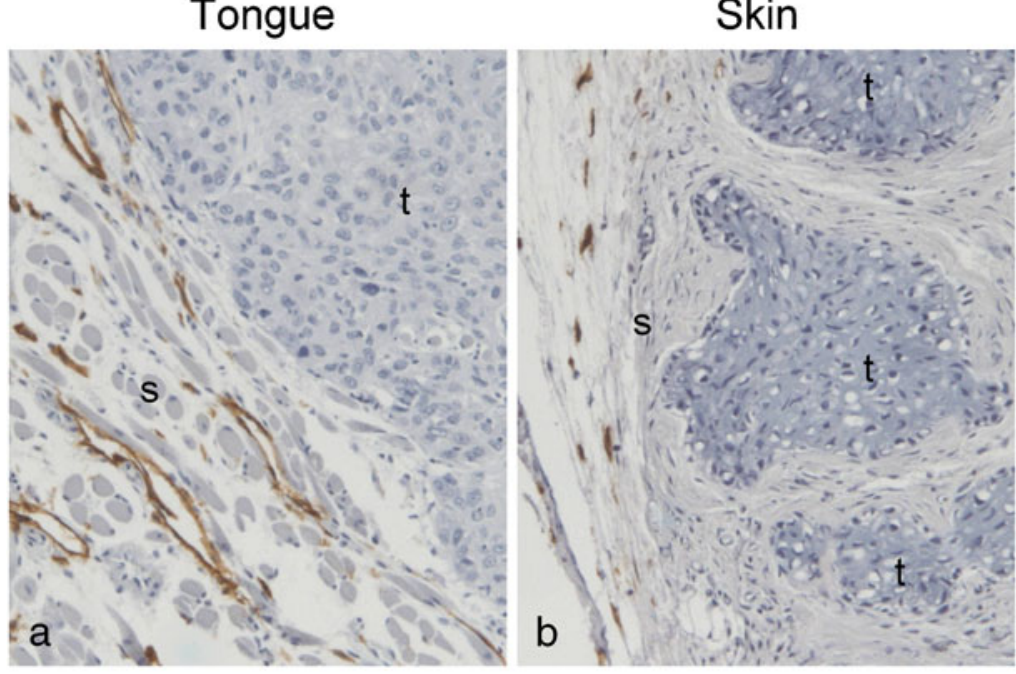

C
10 
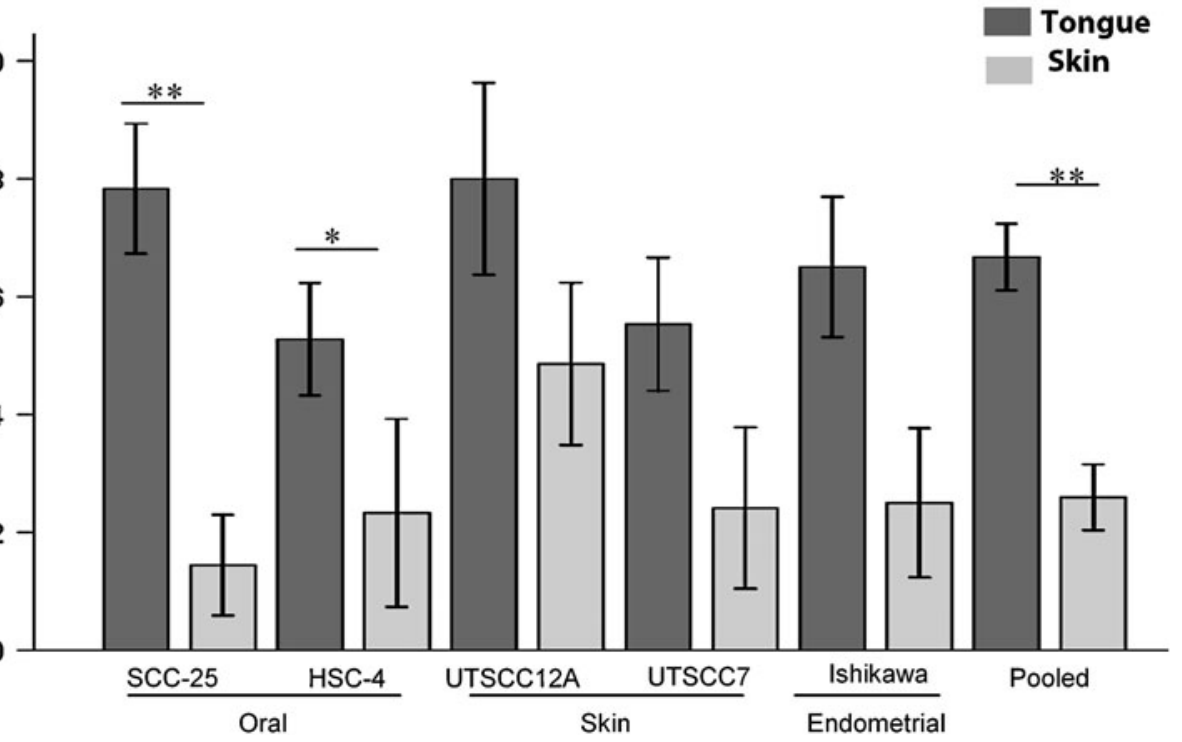

Tongue Skin

Human tongue SCCs have higher lymphatic vessel density than human skin SCCs

To investigate if the density of lymphatic vessels surrounding skin and tongue SCCs in humans showed the same pattern as in our mouse model, tumor tissue from patients with skin or tongue SCCs were immunohistochemically stained with the lymphatic endothelial cell marker podoplanin (D2-40) (Fig. 8). This revealed that lymphatic vessel density was significantly higher in tongue $(17.9 \pm 1.8($ mean $\pm \mathrm{SEM}))$ than in skin $(10.7 \pm 1.1)$ tumors $(P=0.02)$.

Increased number of inflammatory cells in tongue tumors compared with skin tumors in the xenograft model

It is well known that inflammatory mediators contribute significantly to tumor progression $[35,36]$. We therefore

studied the presence of different types of inflammatory cells in the tongue and skin tumors in our xenograft model. For all cell lines the inflammatory infiltrate was more pronounced in tongue tumors compared with the corresponding skin tumors. The number of neutrophils was determined by morphological evaluation of $\mathrm{H} / \mathrm{E}$ stained sections of skin and tongue tumors. The number of neutrophils was two to three times higher in tongue tumors compared with the corresponding skin tumors (Fig. 9a). The number of tumor associated mast cells, assessed by May-Grünwald-Giemsa staining, were also higher in tongue tumors compared with skin tumors for all cell lines, except the UT-SCC-7 cell line where the opposite was seen (Table 6). The number of macrophages, Langerhans and dendritic cells, assessed by CD68-positive cells, was low in both tongue and skin, and further quantification was therefore not performed. 
Fig. 6 Lymphangiogenesis.

Pictures show representative immunohistochemical Lyve-1 staining of tongue tumors of the HSC-4 cell line after a 5 days, b 10 days and $\mathbf{c} 15$ days. Lyve-1 staining is shown in brown and cell nuclei are stained blue. Tumor and stromal areas are indicated with $t$ and $s$, respectively. Original magnification, $100 \times$
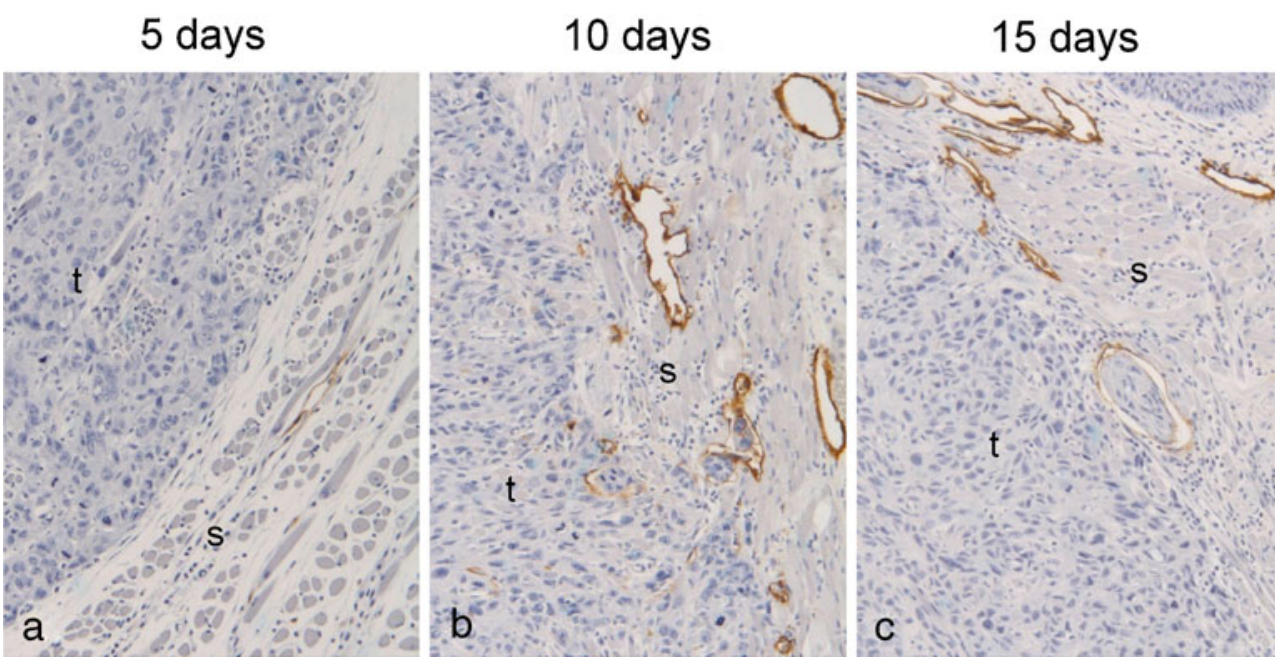

SAP is a major acute phase protein in mice. To investigate if the intensity of the tumor associated inflammation was reflected in the level of this protein, ELISA was used to quantify SAP in plasma from the tumor bearing mice. This revealed that mice with tongue tumors of all cell lines had a slight but consistently higher plasma level of SAP than mice with corresponding skin tumors (Fig. 9b).

\section{Discussion}

Oral cancers mainly metastasize via lymphatic vessels to regional lymph nodes, and there is a well-established association between lymphatic vessel density, lymph node metastases and overall prognosis for oral cancers [13, 37]. It is known that the tumor stroma has a profound impact on
Fig. 7 Lymphatic endothelial growth factors. Pictures show representative immunohistohemical staining with antibodies against VEGF-C (a and b) and VEGF-D (c and d) of tumors of the UTSCC-12A cell line in tongue (a and $\mathbf{c}$ ) and skin (b and d). VEGF$\mathrm{C} /$-D staining is shown in brown and cell nuclei are stained blue. Tumor and stromal areas are indicated with $\mathrm{t}$ and $\mathrm{s}$, respectively. Original magnification, $400 \times$

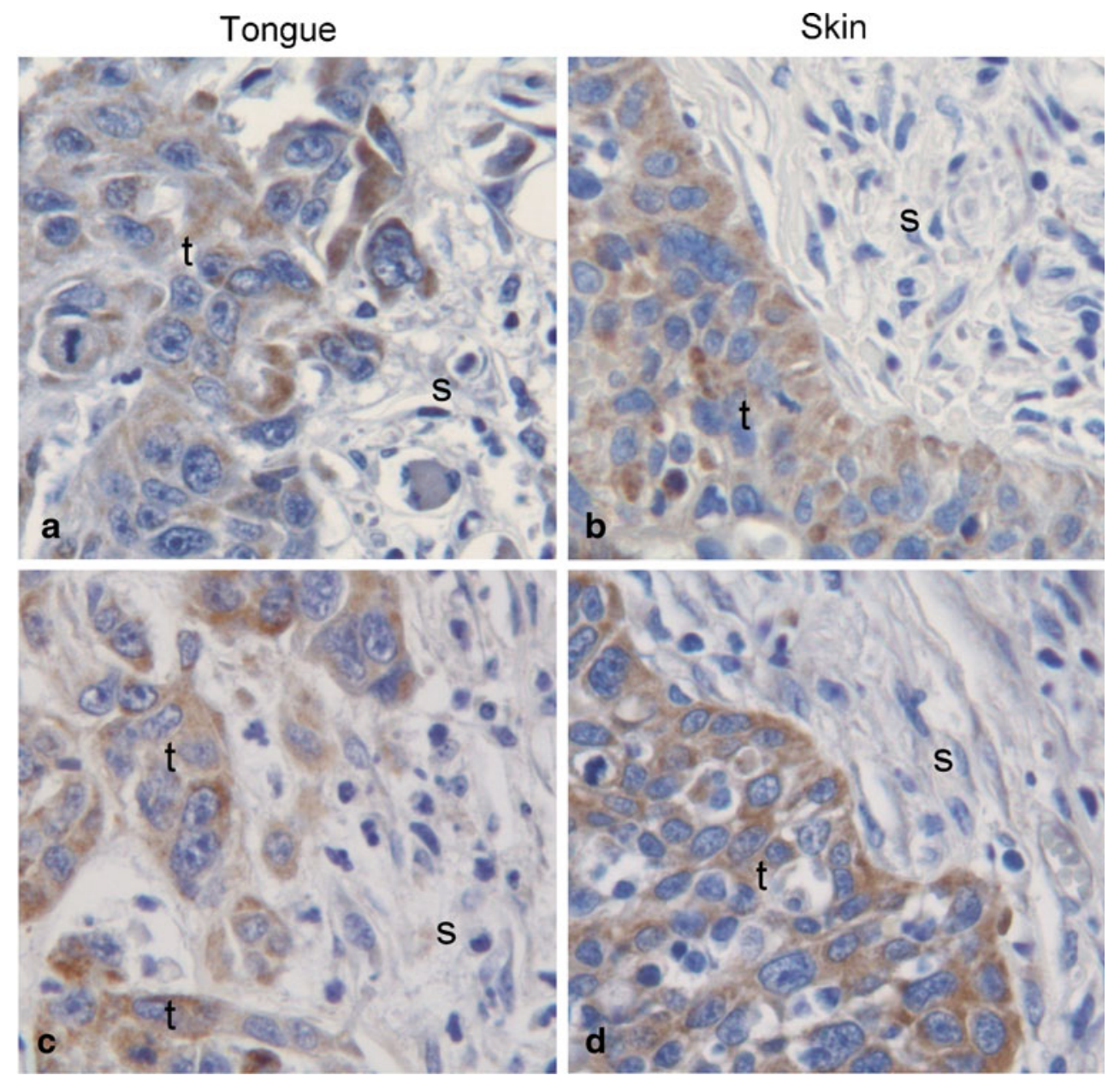


Fig. 8 Lymphatic vessels in human SCCs. Pictures show representative immunohistochemical staining with antibody against podoplanin (D2-40) of tumor tissue from patients with tongue SCC (a) and skin SCC (b). Podoplanin staining is shown in brown and cell nuclei are stained blue. Tumor and stromal areas are indicated with $t$ and $s$, respectively, asterisks indicate area with prominent inflammatory infiltrate. Original magnification, $100 \times$
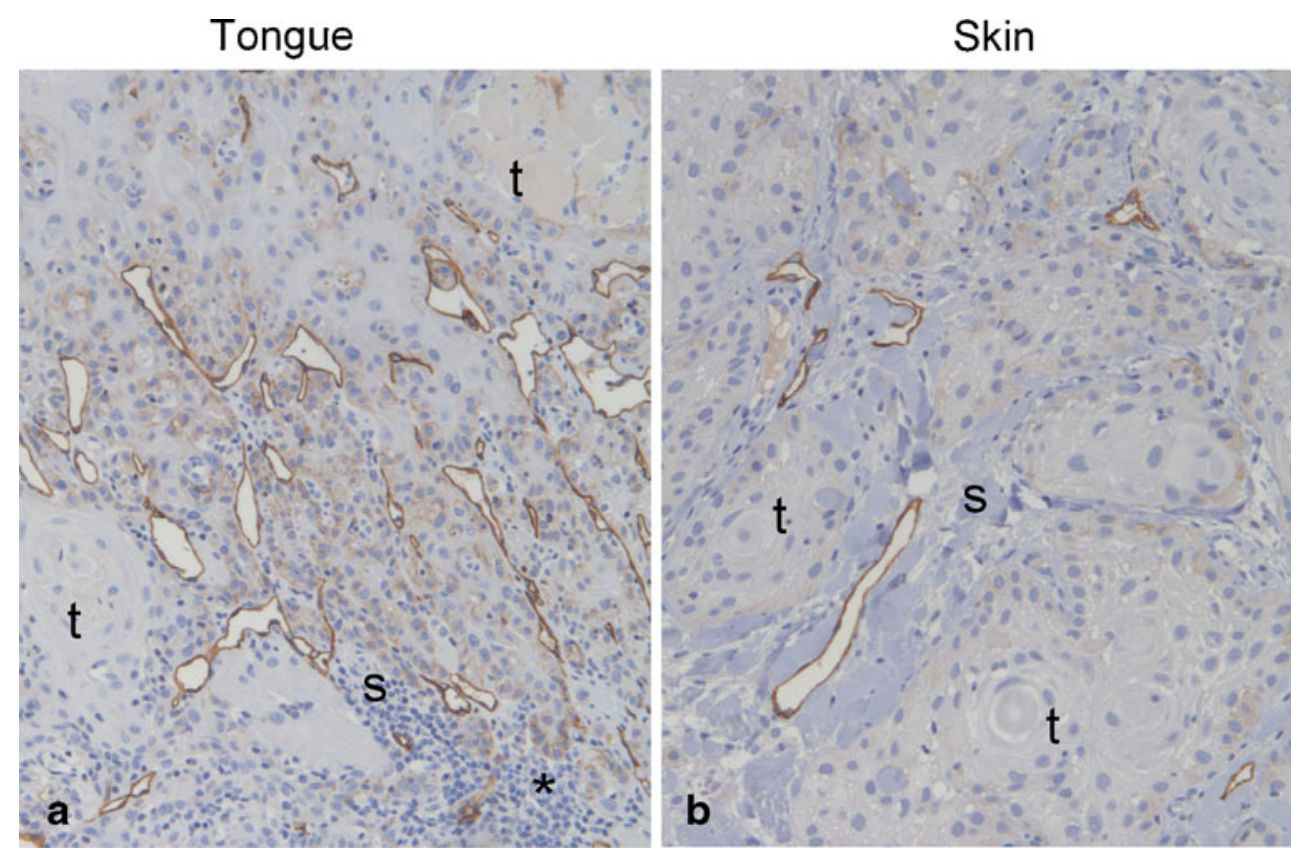

many aspects of cancer development and progression. Lymphangiogenetic growth factors can be produced both by tumor cells and stromal cells, although little is known about the significance of tumor-stroma interactions for lymphangiogenesis. Our xenograft model is well suited for investigating stromal influence on this process. We found that the lymphatic vessel density was much higher in tongue tumors of all cell lines than in the corresponding skin tumors. In the skin, there was a remarkable lack of lymphatic vessels surrounding the majority of the tumors. Those that were seen were mostly located in the subepithelial connective tissue and probably represented preexisting vessels. In general, the tongue tumors were larger than the skin tumors, and this could possibly contribute to the stronger induction of lymphangiogenesis in tongue tumors compared with skin tumors. However, the size differences between tongue and skin tumors of the Ishikawa and the UT-SCC-7 cell lines were rather small, but still the tongue tumors induced much more lymphatic vessel formation than the skin tumors. Therefore, it does not appear to be any significant correlation between tumor size and lymphangiogenesis in our model.

Many aspects of the molecular mechanisms of lymphangiogenesis are obscure. The best established inducers of lymphangiogenesis are the growth factors VEGF-C and VEGF-D, which can be produced by both tumor and stromal cells. These growth factors mainly signal through the VEGFR-3 receptor found on lymphatic endothelial cells and induce proliferation and migration of these cells [17, $38,39]$. Blocking VEGFR-3 signaling has been shown in many studies to inhibit lymphangiogenesis, indicating that the VEGF-C/-D-VEGFR-3 signaling axis is essential for formation of new lymphatic vessels [40, 41]. In the present study, we found that the mRNA level of VEGF-C was twice as high in tongue tumors compared with the corresponding skin tumors. Immunohistochemical staining for VEGF-C and VEGF-D showed no significant difference in staining intensity between tongue and skin tumors. This discrepancy in results at mRNA and protein level may be due to the different sensitivities of the two methods.

VEGF-C and VEGF-D are secreted in an active form that can bind VEGFR-3. However, they can be further processed by proteases in the extracellular environment to a mature form with higher affinity for VEGFR-3 [21, 42]. There was a more prominent inflammatory reaction surrounding the tongue tumors compared with the skin tumors, where neutrophils and mast cells comprised a high proportion of the inflammatory cells. These cell types are known to produce a number of proteolytic enzymes, including MMP-2, MMP-9, MMP-25, tryptases and chymases [43-45]. Higher levels of such proteases in tongue tumors than in skin tumors may result in an increased proteolytic processing of VEGF-C and VEGF-D to the more active forms, and subsequent enhanced lymphangiogenetic signaling in the tongue. In a separate study using the same xenograft model, we have actually shown a significantly increased proteolytic activity in tongue tumors compared with skin tumors [46]. Proteolytic activity is also fundamental for cell migration and for the tissue remodeling required for formation of new vessels [47].

Our analysis of tumors from patients with oral and skin SCCs showed that lymphatic vessel density was significantly higher in tongue compared with skin SCCs (Fig. 8), 
Fig. 9 Assessment of inflammation. a Graph shows mean neutrophil numbers $( \pm$ SEM) of tongue (black bars) and skin (grey bars) tumors of the various cell lines. $N=3$ for all cell lines, and $N=15$ for pooled tongue and skin tumors. ${ }^{*} P<$ 0.05 . b The graph shows mean plasma level of SAP in $\mathrm{ng} / \mathrm{ml} \times$ $10^{4}( \pm$ SEM) in mice with tongue (black bars) and skin (grey bars) tumors of the various cell lines. $N=3$ for all cell lines, except UT-SCC-7 where $N=2$, and $N=14$ for pooled tongue and skin tumors

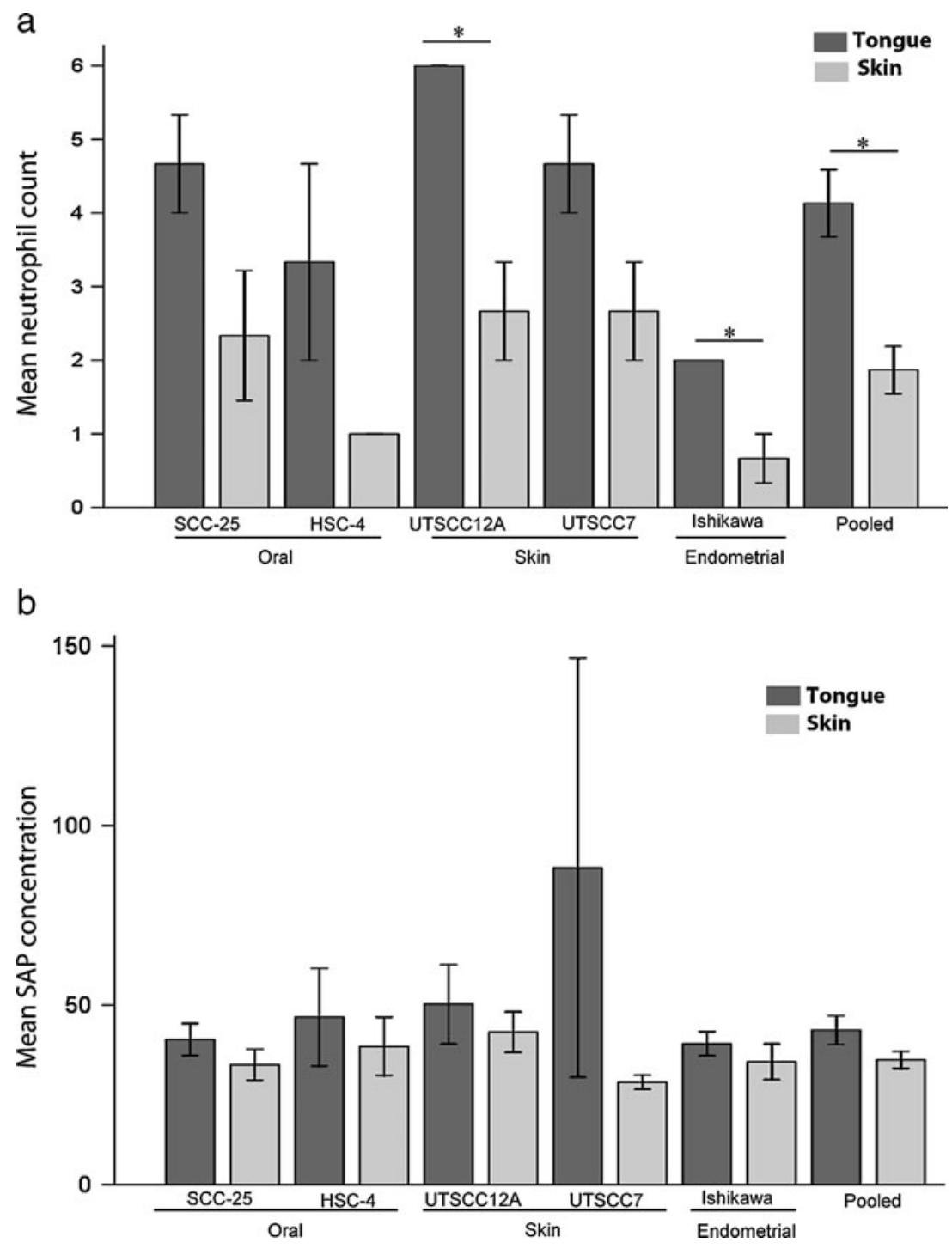

suggesting that our xenograft model reflects clinically relevant aspects of lymphangiogenesis in oral and cutaneous SCCs. The increased lymphangiogenesis in tongue tumors may contribute to the different metastatic

Table 6 Mast cell number

\begin{tabular}{lcll}
\hline Cell line & \multicolumn{2}{l}{ Mean \pm SEM } & $P$ \\
\cline { 2 - 3 } & Tongue & Skin & \\
\hline SCC-25 & $6 \pm 1$ & $3 \pm 0.5$ & 0.140 \\
HSC-4 & $13 \pm 2$ & $4 \pm 1$ & 0.014 \\
UT-SCC-12A & $3 \pm 1$ & $2 \pm 1$ & 0.711 \\
UT-SCC-7 & $5 \pm 1$ & $7 \pm 2$ & 0.545 \\
Ishikawa & $5 \pm 2$ & $3 \pm 1$ & 0.489 \\
Pooled & $6 \pm 1$ & $4 \pm 1$ & 0.058 \\
\hline
\end{tabular}

$N=3$ for all cell lines. $N=15$ for pooled tongue and skin tumors potential of tongue and skin SCCs. Patients with oral SCCs may therefore benefit from treatment targeting lymphangiogenesis.

There are many studies highlighting the importance of angiogenesis in cancer growth and progression [7]. The transition from small dormant tumors to actively growing, invasive and metastatic tumors is shown to be associated with the so-called angiogenic switch, which implies that cancer cells gain the ability to induce formation of new blood vessels [7, 48]. Blood vessel density is further found to correlate with invasiveness and metastasis of many cancers [49-52]. We therefore hypothesized that the differences in growth rate and invasiveness between the tongue and skin tumors in our experiments could be explained by a difference in vascularisation of the tumors in the two organs. To our surprise, we found that the skin tumors were more vascularised than the tongue tumors. Even the smallest and most encapsulated skin tumors had numerous 
blood vessels surrounding them. A clear relationship between mean vessel density and prognosis for patients with oral SCCs is not established, as different studies report conflicting results [53-55]. Sparse vascularisation or rapidly growing tumors can result in areas with hypoxic conditions [56]. Hypoxia provokes adaptive systems in the cancer cells and induces production of substances that regulate metabolism, angiogenesis, $\mathrm{pH}$, cell migration and cell survival [56]. Hypoxia is therefore generally accepted as a promoter of tumor growth, though it can also induce apoptosis [57]. The lower vessel density in the tongue tumors may induce hypoxia which further stimulates a more aggressive progression of the tongue cancers compared with the skin cancers. In accordance with this hypothesis, two recent studies showed that the use of antiangiogenic therapy resulted in increased local invasion and distant metastases in experimental mouse models $[58,59]$.

We found that tumors grew faster in the tongue than in the skin irrespective of the tumor cells' origin. Our results therefore challenge the established belief that cancer cells grow better in ortotopic than in heterotopic environments. To our knowledge there are few studies addressing heterotopic growth of cancer cells in organs associated with aggressive cancers. Our results indicate that the tongue offers a more favorable microenvironment for tumor growth than the skin, which is reflected in the clinical behavior of tongue and skin SCCs in humans. This may partly be related to different structural factors such as different composition of the ECM, resident immunity, temperature and exposure to light or trauma. This further highlights the important role of the stroma in directing growth and progression of cancers.

Acknowledgements This work was supported by grants from The Norwegian Cancer Society, The North Norwegian Regional Health Authorities and The Erna and Olav Aakre Foundation for Cancer Research. The authors are indebted to Professor M. Yanagishita, Tokyo Medical and Dental University, Japan for kindly providing the HSC-4 cell line. The authors thank Dr. P. McCourt for critical reading and linguistic revision of the manuscript.

Conflicts of interest The authors declare that they have no conflict of interest.

Open Access This article is distributed under the terms of the Creative Commons Attribution Noncommercial License which permits any noncommercial use, distribution, and reproduction in any medium, provided the original author(s) and source are credited.

\section{References}

1. Funk GF, Karnell LH, Robinson RA, Zhen WK, Trask DK, Hoffman HT (2002) Presentation, treatment, and outcome of oral cavity cancer: a National Cancer Data Base report. Head Neck 24:165-180
2. Kovacs AF, Stefenelli U, Seitz O, Middendorp M, Diener J, Sader R, Grunwald F (2009) Positive sentinel lymph nodes are a negative prognostic factor for survival in T1-2 oral/oropharyngeal cancer-a long-term study on 103 patients. Ann Surg Oncol $16: 233-239$

3. McGuire JF, Ge NN, Dyson S (2009) Nonmelanoma skin cancer of the head and neck I: histopathology and clinical behavior. Am J Otolaryngol 30:121-133

4. De WO, Mareel M (2003) Role of tissue stroma in cancer cell invasion. J Pathol 200:429-447

5. Pupa SM, Menard S, Forti S, Tagliabue E (2002) New insights into the role of extracellular matrix during tumor onset and progression. J Cell Physiol 192:259-267

6. Sund M, Kalluri R (2009) Tumor stroma derived biomarkers in cancer. Cancer Metastasis Rev 28:177-183

7. Hanahan D, Folkman J (1996) Patterns and emerging mechanisms of the angiogenic switch during tumorigenesis. Cell 86:353-364

8. Leong SP, Cady B, Jablons DM, Garcia-Aguilar J, Reintgen D, Jakub J, Pendas S, Duhaime L, Cassell R, Gardner M, Giuliano R, Archie V, Calvin D, Mensha L, Shivers S, Cox C, Werner JA, Kitagawa Y, Kitajima M (2006) Clinical patterns of metastasis. Cancer Metastasis Rev 25:221-232

9. Banerji S, Ni J, Wang SX, Clasper S, Su J, Tammi R, Jones M, Jackson DG (1999) LYVE-1, a new homologue of the CD44 glycoprotein, is a lymph-specific receptor for hyaluronan. J Cell Biol 144:789-801

10. Kaipainen A, Korhonen J, Mustonen T, van Hinsbergh VW, Fang GH, Dumont D, Breitman M, Alitalo K (1995) Expression of the fms-like tyrosine kinase 4 gene becomes restricted to lymphatic endothelium during development. Proc Natl Acad Sci U S A 92:3566-3570

11. Breiteneder-Geleff S, Soleiman A, Kowalski H, Horvat R, Amann G, Kriehuber E, Diem K, Weninger W, Tschachler E, Alitalo K, Kerjaschki D (1999) Angiosarcomas express mixed endothelial phenotypes of blood and lymphatic capillaries: podoplanin as a specific marker for lymphatic endothelium. Am J Pathol 154:385394

12. Dadras SS, Lange-Asschenfeldt B, Velasco P, Nguyen L, Vora A, Muzikansky A, Jahnke K, Hauschild A, Hirakawa S, Mihm MC, Detmar M (2005) Tumor lymphangiogenesis predicts melanoma metastasis to sentinel lymph nodes. Mod Pathol $18: 1232-1242$

13. Zhao D, Pan J, Li XQ, Wang XY, Tang C, Xuan M (2008) Intratumoral lymphangiogenesis in oral squamous cell carcinoma and its clinicopathological significance. J Oral Pathol Med 37:616-625

14. Renyi-Vamos F, Tovari J, Fillinger J, Timar J, Paku S, Kenessey I, Ostoros G, Agocs L, Soltesz I, Dome B (2005) Lymphangiogenesis correlates with lymph node metastasis, prognosis, and angiogenic phenotype in human non-small cell lung cancer. Clin Cancer Res 11:7344-7353

15. Gombos Z, Xu X, Chu CS, Zhang PJ, Acs G (2005) Peritumoral lymphatic vessel density and vascular endothelial growth factor $\mathrm{C}$ expression in early-stage squamous cell carcinoma of the uterine cervix. Clin Cancer Res 11:8364-8371

16. Karkkainen MJ, Haiko P, Sainio K, Partanen J, Taipale J, Petrova TV, Jeltsch M, Jackson DG, Talikka M, Rauvala H, Betsholtz C, Alitalo K (2004) Vascular endothelial growth factor C is required for sprouting of the first lymphatic vessels from embryonic veins. Nat Immunol 5:74-80

17. Makinen T, Veikkola T, Mustjoki S, Karpanen T, Catimel B, Nice EC, Wise L, Mercer A, Kowalski H, Kerjaschki D, Stacker SA, Achen MG, Alitalo K (2001) Isolated lymphatic endothelial cells transduce growth, survival and migratory signals via the VEGF-C/D receptor VEGFR-3. EMBO J 20:4762-4773 
18. Joukov V, Pajusola K, Kaipainen A, Chilov D, Lahtinen I, Kukk E, Saksela O, Kalkkinen N, Alitalo K (1996) A novel vascular endothelial growth factor, VEGF-C, is a ligand for the Flt4 (VEGFR-3) and KDR (VEGFR-2) receptor tyrosine kinases. EMBO J 15:290-298

19. Achen MG, Jeltsch M, Kukk E, Makinen T, Vitali A, Wilks AF, Alitalo K, Stacker SA (1998) Vascular endothelial growth factor D (VEGF-D) is a ligand for the tyrosine kinases VEGF receptor 2 (Flk1) and VEGF receptor 3 (Flt4). Proc Natl Acad Sci USA 95:548-553

20. Petrova TV, Bono P, Holnthoner W, Chesnes J, Pytowski B, Sihto H, Laakkonen P, Heikkila P, Joensuu H, Alitalo K (2008) VEGFR-3 expression is restricted to blood and lymphatic vessels in solid tumors. Cancer Cell 13:554-556

21. Joukov V, Sorsa T, Kumar V, Jeltsch M, Claesson-Welsh L, Cao Y, Saksela O, Kalkkinen N, Alitalo K (1997) Proteolytic processing regulates receptor specificity and activity of VEGFC. EMBO J 16:3898-3911

22. Killion JJ, Radinsky R, Fidler IJ (1998) Orthotopic models are necessary to predict therapy of transplantable tumors in mice. Cancer Metastasis Rev 17:279-284

23. Myers JN, Holsinger FC, Jasser SA, Bekele BN, Fidler IJ (2002) An orthotopic nude mouse model of oral tongue squamous cell carcinoma. Clin Cancer Res 8:293-298

24. Grenman R, Pekkola-Heino K, Joensuu H, Aitasalo K, Klemi P, Lakkala T (1992) UT-MUC-1, a new mucoepidermoid carcinoma cell line, and its radiosensitivity. Arch Otolaryngol Head Neck Surg 118:542-547

25. Hadler-Olsen E, Kanapathippillai P, Berg E, Svineng G, Winberg JO, Uhlin-Hansen L (2010) Gelatin in situ zymography on fixed, paraffin-embedded tissue: zinc and ethanol fixation preserve enzyme activity. J Histochem Cytochem 58:29-39

26. Weidner N, Carroll PR, Flax J, Blumenfeld W, Folkman J (1993) Tumor angiogenesis correlates with metastasis in invasive prostate carcinoma. Am J Pathol 143:401-409

27. Kobel M, Weichert W, Cruwell K, Schmitt WD, Lautenschlager C, Hauptmann S (2004) Epithelial hyaluronic acid and CD44v6 are mutually involved in invasion of colorectal adenocarcinomas and linked to patient prognosis. Virchows Arch 445:456-464

28. Livak KJ, Schmittgen TD (2001) Analysis of relative gene expression data using real-time quantitative PCR and the 2(-Delta Delta C(T)) Method. Methods 25:402-408

29. Schledzewski K, Falkowski M, Moldenhauer G, Metharom P, Kzhyshkowska J, Ganss R, Demory A, Falkowska-Hansen B, Kurzen H, Ugurel S, Geginat G, Arnold B, Goerdt S (2006) Lymphatic endothelium-specific hyaluronan receptor LYVE-1 is expressed by stabilin-1+, F4/80+, CD11b+macrophages in malignant tumours and wound healing tissue in vivo and in bone marrow cultures in vitro: implications for the assessment of lymphangiogenesis. J Pathol 209:67-77

30. Wrobel T, Dziegiel P, Mazur G, Zabel M, Kuliczkowski K, Szuba A (2005) LYVE-1 expression on high endothelial venules (HEVs) of lymph nodes. Lymphology 38:107-110

31. Salven P, Mustjoki S, Alitalo R, Alitalo K, Rafii S (2003) VEGFR-3 and CD133 identify a population of CD34+ lymphatic/ vascular endothelial precursor cells. Blood 101:168-172

32. Jiang S, Bailey AS, Goldman DC, Swain JR, Wong MH, Streeter PR, Fleming WH (2008) Hematopoietic stem cells contribute to lymphatic endothelium. PLoS ONE 3:e3812

33. Religa P, Cao R, Bjorndahl M, Zhou Z, Zhu Z, Cao Y (2005) Presence of bone marrow-derived circulating progenitor endothelial cells in the newly formed lymphatic vessels. Blood 106:4184 4190

34. Conrad C, Niess H, Huss R, Huber S, von Luettichau I, Nelson PJ, Ott HC, Jauch KW, Bruns CJ (2009) Multipotent mesenchymal stem cells acquire a lymphendothelial phenotype and enhance lymphatic regeneration in vivo. Circulation 119:281-289

35. Murdoch C, Muthana M, Coffelt SB, Lewis CE (2008) The role of myeloid cells in the promotion of tumour angiogenesis. Nat Rev Cancer 8:618-631

36. Kundu JK, Surh YJ (2008) Inflammation: gearing the journey to cancer. Mutat Res 659:15-30

37. Beasley NJ, Prevo R, Banerji S, Leek RD, Moore J, van Trappen TP, Cox G, Harris AL, Jackson DG (2002) Intratumoral lymphangiogenesis and lymph node metastasis in head and neck cancer. Cancer Res 62:1315-1320

38. Jeltsch M, Kaipainen A, Joukov V, Meng X, Lakso M, Rauvala H, Swartz M, Fukumura D, Jain RK, Alitalo K (1997) Hyperplasia of lymphatic vessels in VEGF-C transgenic mice. Science 276:1423-1425

39. Veikkola T, Jussila L, Makinen T, Karpanen T, Jeltsch M, Petrova TV, Kubo H, Thurston G, McDonald DM, Achen MG, Stacker SA, Alitalo K (2001) Signalling via vascular endothelial growth factor receptor-3 is sufficient for lymphangiogenesis in transgenic mice. EMBO J 20:1223-1231

40. Roberts N, Kloos B, Cassella M, Podgrabinska S, Persaud K, Wu Y, Pytowski B, Skobe M (2006) Inhibition of VEGFR-3 activation with the antagonistic antibody more potently suppresses lymph node and distant metastases than inactivation of VEGFR-2. Cancer Res 66:2650-2657

41. Burton JB, Priceman SJ, Sung JL, Brakenhielm E, An DS, Pytowski B, Alitalo K, Wu L (2008) Suppression of prostate cancer nodal and systemic metastasis by blockade of the lymphangiogenic axis. Cancer Res 68:7828-7837

42. Stacker SA, Stenvers K, Caesar C, Vitali A, Domagala T, Nice E, Roufail S, Simpson RJ, Moritz R, Karpanen T, Alitalo K, Achen MG (1999) Biosynthesis of vascular endothelial growth factor-D involves proteolytic processing which generates non-covalent homodimers. J Biol Chem 274:32127-32136

43. Borregaard N, Sorensen OE, Theilgaard-Monch K (2007) Neutrophil granules: a library of innate immunity proteins. Trends Immunol 28:340-345

44. Pejler G, Abrink M, Ringvall M, Wernersson S (2007) Mast cell proteases. Adv Immunol 95:167-255

45. Stevens RL, Adachi R (2007) Protease-proteoglycan complexes of mouse and human mast cells and importance of their betatryptase-heparin complexes in inflammation and innate immunity. Immunol Rev 217:155-167

46. Hadler-Olsen E et al. (2010) Organ specific regulation of tumour invasiveness and gelatinolytic activity at the invasive front. Eur J Cancer. doi:10.1016/j.ejca.2010.09.006

47. Deryugina EI, Quigley JP (2006) Matrix metalloproteinases and tumor metastasis. Cancer Metastasis Rev 25:9-34

48. Naumov GN, Akslen LA, Folkman J (2006) Role of angiogenesis in human tumor dormancy: animal models of the angiogenic switch. Cell Cycle 5:1779-1787

49. Depasquale I, Thompson WD (2005) Microvessel density for melanoma prognosis. Histopathology 47:186-194

50. Macchiarini P, Fontanini G, Hardin MJ, Squartini F, Angeletti CA (1992) Relation of neovascularisation to metastasis of non-smallcell lung cancer. Lancet 340:145-146

51. Salvesen HB, Gulluoglu MG, Stefansson I, Akslen LA (2003) Significance of CD 105 expression for tumour angiogenesis and prognosis in endometrial carcinomas. APMIS 111:1011-1018

52. Weidner N, Folkman J, Pozza F, Bevilacqua P, Allred EN, Moore DH, Meli S, Gasparini G (1992) Tumor angiogenesis: a new significant and independent prognostic indicator in early-stage breast carcinoma. J Natl Cancer Inst 84:1875-1887

53. Hannen EJ, Riediger D (2004) The quantification of angiogenesis in relation to metastasis in oral cancer: a review. Int $\mathrm{J}$ Oral Maxillofac Surg 33:2-7 
54. Ranieri G, Labriola A, Achille G, Florio G, Zito AF, Grammatica L, Paradiso A (2002) Microvessel density, mast cell density and thymidine phosphorylase expression in oral squamous carcinoma. Int J Oncol 21:1317-1323

55. Tae K, El-Naggar AK, Yoo E, Feng L, Lee JJ, Hong WK, Hittelman WN, Shin DM (2000) Expression of vascular endothelial growth factor and microvessel density in head and neck tumorigenesis. Clin Cancer Res 6:2821-2828

56. Rademakers SE, Span PN, Kaanders JH, Sweep FC, van der Kogel AJ, Bussink J (2008) Molecular aspects of tumour hypoxia. Mol Oncol 2:41-53
57. Ruan K, Song G, Ouyang G (2009) Role of hypoxia in the hallmarks of human cancer. J Cell Biochem 107:1053-1062

58. Paez-Ribes M, Allen E, Hudock J, Takeda T, Okuyama H, Vinals F, Inoue M, Bergers G, Hanahan D, Casanovas O (2009) Antiangiogenic therapy elicits malignant progression of tumors to increased local invasion and distant metastasis. Cancer Cell $15: 220-231$

59. Ebos JM, Lee CR, Cruz-Munoz W, Bjarnason GA, Christensen JG, Kerbel RS (2009) Accelerated metastasis after short-term treatment with a potent inhibitor of tumor angiogenesis. Cancer Cell 15:232-239 